\title{
Correlation Between Gender and Knowledge, with Practice and Referral Rate of Continuum Rehabilitation Cases by General Practitioners
}

\section{Hari Peni Julianti, Angela BM Tulaar, Tirza Z Tamin, Tanti Ajoe Kesoema, Endang Ambarwati, Sri Wahyudati}

Department of Physical Medicine and Rehabilitation, Faculty of Medicine, University of Diponegoro, Semarang, Indonesia

Department of Physical Medicine and Rehabilitation, Faculty of Medicine, University of Indonesia, Jakarta, Indonesia

\begin{abstract}
Introduction: Indonesian Health Ministry had a strategy to make the primary care, including rhabilitation program by continuum of care. The purpose of this study was to determine factors related to the level of knowledge, practice, and referral for continuum care cases that required rehabilitation services in Primary Health Care Doctors.

Methods: The study design was cross-sectional. Participants were 23 Primary Health Care Doctors in Wonosobo District. Data collection was conducted in December 2017. The independent variables consist of gender, length of work, employment status, while the dependent variables were the level of knowledge, practice and referral cases of maternal, infants and toddlers, adolescents, adults and elderly. The measuring instrument was a questionnaire. Data were tested with chi-square, significance level $<0.05$.

Results: Gender has correlation with the level of knowledge in maternal cases $(\mathrm{PR}=0.121,95 \% \mathrm{CI}=$ $0.017-0.087, \mathrm{p}=0.026)$. Gender has correlation to the level of practice in maternal case $(\mathrm{PR}=0.121$, $95 \% \mathrm{CI}=0.017-0.867, \mathrm{p}=0.026)$. Employment status has correlation to the referral rate of elderly cases $(\mathrm{PR}=10.500,95 \% \mathrm{CI}=1.015-108.577, \mathrm{p}=0.029)$.
\end{abstract}

Conclusion: Gender has correlation with the level of knowledge and practice of maternal cases. Employment status has correlation with the level of referral rate of elderly cases.

Keywords: Primary care doctors, Knowledge, Referral, Continuum Rehabilitation 


\section{ABSTRAK}

Pendahuluan: Rencana Strategi Kementerian Kesehatan Indonesia adalah penguatan layanan primer termasuk rehabilitasi melalui pendekatan continuum of care. Tujuan penelitian untuk mengetahui faktor-faktor yang berhubungan dengan tingkat pengetahuan, praktik, rujukan kasus yang memerlukan pelayanan rehabilitasi berkelanjutan pada dokter Puskesmas.

Metode: Desain penelitian adalah cross sectional. Partisipan adalah 23 dokter Puskesmas di Kabupaten Wonosobo. Data dikumpulkan pada Desember 2017. Variabel bebas terdiri dari jenis kelamin, lama bekerja, status kepegawaian, sedangkan variabel terikat adalah tingkat pengetahuan, tingkat praktik dan tingkat rujukan kasus maternal, bayi dan balita, remaja, dewasa dan lanjut usia (lansia). Alat ukur yang digunakan adalah kuesioner. Data diuji dengan chi square, tingkat kemaknaan $<0,05$.

Hasil: Jenis kelamin berhubungan dengan pengetahuan kasus maternal $($ Rasio Prevalens $(\mathrm{RP})=0,121,95 \% \mathrm{CI}=$ $0,017-0,087, p=0,026)$. Jenis kelamin berhubungan dengan tingkat praktik kasus maternal $(\mathrm{RP}=0,121,95 \% \mathrm{CI}$

$=0,017-0,867, \mathrm{p}=0,026)$. Status kepegawaian berhubungan dengan tingkat rujukan kasus lansia $(\mathrm{RP}=10,500$, $95 \% \mathrm{CI}=1,015-108,577, \mathrm{p}=0,029)$.

Kesimpulan: Jenis kelamin berhubungan dengan tingkat pengetahuan dan tingkat praktik kasus maternal. Status kepegawaian berhubungan dengan tingkat rujukan kasus lansia.

Kata kunci: Dokter Puskesmas, Pengetahuan, rujukan, Rehabilitasi berkelanjutan

\section{Correspondent Detail:}

\section{Hari Peni Julianti}

Email: hari.peni@yahoo.com

Department of Physical Medicine and Rehabilitation,

Faculty of Medicine University of Diponegoro Semarang, Indonesia

\section{INTRODUCTION}

The vision of the Indonesian governmentin the field of health is the realization of excellent quality of Indonesian communities. The Ministry of Health has constructed a strategic plan in order to accomplish these goals, with one of them being the strengthening of primary health services, including rehabilitation services through the continuum of care approach. It is essential for primary health care (Puskesmas) doctors who work in primary health care to acquire exceptional knowledge about rehabilitation services in pregnant and post-partum mothers, infants and children, adolescents, adults and the elderly. The ability to diagnose and handle rehabilitation services in cases of continuum of care is paramount as these are part of a clinician's competence and in order to make referrals beyond their competence. ${ }^{1}$

Formerly, no research has analyzed factors related to knowledge, practice and referral of continuum of care cases that require rehabilitation services for doctors in Primary health centers. Therefore, it is necessary to conduct a research in order to analyze the factors associated with the level of 
knowledge, practice, and continuum of care cases referral, which requires the rehabilitation services of primary health center doctors.

\section{METHODS}

The study design was cross-sectional. Participants were 23 Primary Health Care Doctors in Wonosobo District, Central Java, Indonesia. Data collection was conducted in December 2017. The independent variables were gender, length of work, employment status, level of knowledge, level of practice, while the dependent variables were the level of knowledge, level of practice and level of referral in cases of maternal, infants and children or pediatric, adolescents, adults and elderly.

The measuring instrument was a questionnaire. The questionnaire was validated by three experts and was tested. The knowledge questionnaire consisted of open-ended questions about maternal, child, adult, adolescent and elderly cases requiring rehabilitation services. The practice questionnaire consists of open-ended questions about the practice of maternal, child, adult, adolescent and elderly cases that require rehabilitation services that have been handled. Questionnaire for referral questions consists of open-ended questions about maternal, child, adult, adolescent and elderly referral cases that require rehabilitation services that have been performed by doctors in primary health care The level of knowledge, practice, and continuum of care cases referral which requires the rehabilitation services of primary health care doctors was stated as good if the research subjects get more or equal to 70 and were declared less if they get less than 70. Data were tested with chisquare, significance level $<0.05$.

\section{RESULTS}

Research subjects were 15 female (65.20\%). All of subjects had medical education background, and no subjects with postgraduate or specialties degree. Mean of length of work were $7.48 \pm$ 5,517 years, with a minimum of 1 year, and a maximum 18 years. Fourteen subjects (60,90\%) have worked more than 5 years. The employment status of the subjects consisted of $56.0 \%$ having the status of civil servants, $34,80 \%$ BLUD (Badan Layanan Umum Daerah) employees, and $8.70 \%$ private workers. All of subjects have no experience in attending seminars or courses related to rehabilitation and never received any lectures related to rehabilitation in medical school. All research subjects rarely read articles about rehabilitation services in scientific journals or websites. All study subjects said there was no rehabilitation or physiotherapy specialty clinic in primary health care.

The results showed that $56.50 \%, 56.50 \%$, and $82.60 \%$ subjects had lack level of knowledge, practice, and referral in maternal cases, respectively. As much of $52.20 \%$ subjects had favorable level of knowledge and practice in pediatric cases, however as much of $56.50 \%$ subjects have lack of pediatrics referral rate. As much of $52.20 \%$ subjects had lack level of knowledge and practices in adolescent cases, and $82.60 \%$ of subjects had lack referral adolescent cases. As much as $56.50 \%$ subjects had favorable knowledge in adult cases, while $52.20 \%$ and $73.90 \%$ of subjects had lack practices and referral rates of adult cases, respectively. As much as $65.20 \%$ of subjects had a good level of knowledge and practice of geriatric cases, while $65.20 \%$ of subjects had lack referral rate geriatric cases. 
All research subjects treat continuum of care cases with funding from the government's national health insurance (BPJS), hence no subject is able to make a direct referral to a physical medicine and rehabilitation doctor. All of the subjects made referrals to obstetricians and gynecologists, as well as referrals to neurologists in maternal cases requiring rehabilitation such as ischialgia, severe low back pain, and carpal tunnel syndrome.

All research subjects have referred to pediatricians in infants and children who required rehabilitation services, including cerebral palsy, growth and developmental disorders. All subjects referred to pediatricians, surgeons or specialists in adolescent cases on fracture cases. All subjects referred adult and elderly to internists, neurologists and surgeons in cases of back pain and knee pain.

The results showed that the gender was related to knowledge in maternal case $(\mathrm{RP}=0.121,95 \%$ $\mathrm{CI}=0.017-0.087, \mathrm{p}=0.026)$. The relationship between gender, length of work, employment status and level of knowledge in maternal, pediatrics, adolescents, adults, and elderly cases can be seen in Table 1.

Table 1. The relationship between gender, length of work, employment status and level of knowledge in maternal, pediatric, adolescent, adult, and elderly cases.

\begin{tabular}{|c|c|c|c|}
\hline No & Variable & $\begin{array}{c}\text { Prevalance Ratio } \\
\text { 95\% Confidence Interval }\end{array}$ & $P$ value \\
\hline 1 & $\begin{array}{l}\text { Maternal cases: Gender and level of knowledge } \\
\text { Length of work and level of knowledge } \\
\text { Employment status and level of knowledge }\end{array}$ & $\begin{array}{c}0.121 \\
0.017-0.087 \\
2,000 \\
0,352-11,364 \\
1,286 \\
0.242-6.831\end{array}$ & $\begin{array}{l}0.026 * \\
0.431 \\
0.768\end{array}$ \\
\hline 2 & $\begin{array}{l}\text { Pediatric cases: } \\
\text { Gender and level of knowledge } \\
\text { Length of work and level of knowledge } \\
\text { Employment status and level of knowledge } \\
\text { of pediatric cases }\end{array}$ & $\begin{array}{c}0.222 \\
0.033-1,493 \\
1,667 \\
0,308-9,014 \\
0.571 \\
0.108-3.036 \\
\end{array}$ & $\begin{array}{l}0.110 \\
0.552 \\
0.510\end{array}$ \\
\hline 3 & $\begin{array}{l}\text { Adolescent cases: } \\
\text { Gender and level of knowledge } \\
\text { Length of work and level of knowledge } \\
\text { Employment status and level of knowledge }\end{array}$ & $\begin{array}{c}0.167 \\
0.024-1.445 \\
1,250 \\
0.233-6.715 \\
1,750 \\
0,329-9,298 \\
\end{array}$ & $\begin{array}{l}0.057 \\
0.795 \\
0.510\end{array}$ \\
\hline 4 & $\begin{array}{l}\text { Adult cases: } \\
\text { Gender and level of knowledge } \\
\text { Length of work and level of knowledge } \\
\text { Employment status and level of knowledge }\end{array}$ & $\begin{array}{c}0.292 \\
0.044-1.940 \\
1,067 \\
0,197-5,769 \\
1,600 \\
0.302-8.490 \\
\end{array}$ & $\begin{array}{l}0.192 \\
0.940 \\
0.580\end{array}$ \\
\hline 5 & $\begin{array}{l}\text { Geriatric cases: } \\
\text { Gender and level of knowledge } \\
\text { Length of work and level of knowledge } \\
\text { Employment status and level of knowledge }\end{array}$ & $\begin{array}{c}0.216 \\
0.016-1.675) \\
1,900 \\
0.154-5.258 \\
1,500 \\
0.266-8.445\end{array}$ & $\begin{array}{l}0.101 \\
0.907 \\
0.645\end{array}$ \\
\hline
\end{tabular}

*Chi squre, significant $\mathrm{p}<0.05$ 
Gender $(\mathrm{RP}=0.121,95 \% \mathrm{CI}=0.017-0.867, \mathrm{p}=0.026)$ was related to the level of maternal case practice. The relationship between gender, length of work, employment status and level of practice in maternal, pediatrics, adolescents, adults, and elderly cases can be seen in Table 2.

Table 2. The relationship of gender, length of work, employment status and the level of practice in maternal, pediatric, adolescent, adult and the elderly cases.

\begin{tabular}{|c|c|c|c|}
\hline No & Variable & $\begin{array}{c}\text { Prevalance Ratio } \\
\text { 95\% Confidence Interval }\end{array}$ & $P$ value \\
\hline 1 & $\begin{array}{l}\text { Maternal cases: Gender and level of practice } \\
\text { Length of work and level of practice } \\
\text { Employment status with level of practice }\end{array}$ & $\begin{array}{c}0.121 \\
0.017-0.867 \\
0.938 \\
0.173-5.070 \\
1.286 \\
0.242-6,631 \\
\end{array}$ & $\begin{array}{l}0.026 * \\
0.940 \\
0.768\end{array}$ \\
\hline 2 & $\begin{array}{l}\text { Pediatric cases: } \\
\text { Gender and level of practice } \\
\text { Length of work and level of practice } \\
\text { Employment status and level of practice }\end{array}$ & $\begin{array}{c}0.222 \\
0.033-1,493 \\
3.600 \\
0.616-21.033 \\
5.250 \\
0.874-31,533 \\
\end{array}$ & $\begin{array}{l}0.110 \\
0.147 \\
0.069\end{array}$ \\
\hline 3 & $\begin{array}{l}\text { Adolescent cases: } \\
\text { Gender and level of practice } \\
\text { Length of work and level of practice } \\
\text { Employment status and level of practice }\end{array}$ & $\begin{array}{c}0.167 \\
0.024-1.145 \\
1.250 \\
0.233-6.715 \\
3.733 \\
0.646-21.577 \\
\end{array}$ & $\begin{array}{l}0.057 \\
0.795 \\
0.133 \\
\end{array}$ \\
\hline 4 & $\begin{array}{l}\text { Adult cases: } \\
\text { Gender with level of practice } \\
\text { Length of work with level of practice } \\
\text { Employment status with level of practice }\end{array}$ & $\begin{array}{c}0.167 \\
0.024-1.145 \\
1.250 \\
0.233-6.715 \\
3.733 \\
0.646-21.577 \\
\end{array}$ & $\begin{array}{l}0.057 \\
0.795 \\
0.133 \\
\end{array}$ \\
\hline 5 & $\begin{array}{l}\text { Geriatric cases: } \\
\text { Gender with level of practice } \\
\text { Length with level of practice } \\
\text { Employment status with level of practice }\end{array}$ & $\begin{array}{c}1.200 \\
0.201-7.162 \\
0.381 \\
0.057-2.534 \\
1.500 \\
0.266-8.445\end{array}$ & $\begin{array}{l}0.842 \\
0.311 \\
0.645\end{array}$ \\
\hline
\end{tabular}

* Chi square, significant $\mathrm{p}<0.05$

The employment status $(\mathrm{RP}=10,500,95 \% \mathrm{CI}=1,015-108,577, \mathrm{p}=0.029)$ was related to the referral rate of elderly cases. The relationship between gender, length of work, employment status and level of referral in maternal cases, pediatrics, adolescents, adults, and elderly can be seen in Table 3 . 
Table 3 . The relationship of gender, length of work, and employment status and the level of referral in maternal cases, paediatrics, adolescent, adult and elderly.

\begin{tabular}{|c|c|c|c|}
\hline No & Variable & $\begin{array}{c}\text { Prevalance Ratio } \\
\text { 95\% Confidence Interval }\end{array}$ & P value \\
\hline 1 & $\begin{array}{l}\text { Maternal cases: } \\
\text { Gender and referral rate } \\
\text { Length of work and referral rate } \\
\text { Employment status and referral rate }\end{array}$ & $\begin{array}{c}0.119 \\
0.010-1.426 \\
2.182 \\
0.190-25.021 \\
2.700 \\
0.236-30.846\end{array}$ & $\begin{array}{l}0.063 \\
0.524 \\
0.412\end{array}$ \\
\hline 2 & $\begin{array}{l}\text { Pediatric cases: Gender and referral rate } \\
\text { Length of work and referral rate } \\
\text { Employment status and referral rate }\end{array}$ & $\begin{array}{c}0.300 \\
0.050-1.795 \\
2.000 \\
0.352-11.364 \\
2.722 \\
0.479-15.468\end{array}$ & $\begin{array}{l}0.179 \\
0.431 \\
0.253\end{array}$ \\
\hline 3 & $\begin{array}{l}\text { Adolescent cases: } \\
\text { Gender and referral rate } \\
\text { Length of work and referral rate } \\
\text { Employment status and referral rate }\end{array}$ & $\begin{array}{c}0.462 \\
0.052-4,106 \\
2.182 \\
0.190-25.021 \\
1.444 \\
1.005-2.075 \\
\end{array}$ & $\begin{array}{l}0.482 \\
0.524 \\
0.054 \\
\end{array}$ \\
\hline 4 & $\begin{array}{l}\text { Adult cases: Gender and referral rate } \\
\text { Length of work and referral rate } \\
\text { Employment status and referral rate }\end{array}$ & $\begin{array}{c}0.417 \\
0.062-2.815 \\
1,400 \\
0.199-9.869 \\
5.625 \\
0.537-5.8909\end{array}$ & $\begin{array}{l}0.363 \\
0.735 \\
0.123\end{array}$ \\
\hline 5 & $\begin{array}{l}\text { Geriatric cases: Gender and referral rate } \\
\text { Length of work and referral rate } \\
\text { Employment status and referral rate }\end{array}$ & $\begin{array}{c}0.364 \\
0.060-2.194 \\
2.625 \\
0.395-17.458 \\
10.500 \\
1.015-108.577\end{array}$ & $\begin{array}{c}0.263 \\
0.311 \\
0.029 *\end{array}$ \\
\hline
\end{tabular}

*Chi square, significant $\mathrm{p}<0.05$

There was relationship between; the level of knowledge and the level of practice in maternal cases $\quad(\mathrm{PR}=7,778, \quad 95 \% \mathrm{CI}=1,200-50,424$, $\mathrm{p}=0,024)$, the level of knowledge and the level of practice in adolescent cases $(\mathrm{PR}=110,000$, $95 \% \mathrm{CI}=6,046-200,324, \mathrm{p}=0,000)$, the level of knowledge and the level of practice in adult cases $\quad(\mathrm{P}=30,000, \quad 95 \% \mathrm{CI}=2,626-342,734$, $\mathrm{p}=0,001)$, the level of practice and the referral rate in adult cases $(\mathrm{P}=9,167,95 \% \mathrm{CI}=0,860$ -
97,694, $\mathrm{p}=0,043$ ), the level of knowledge of elderly cases and the level of practice in elderly cases $(\mathrm{P}=19,500, \quad 95 \% \mathrm{CI}=2,192$ $173,486, p=0,003)$.

The relation between the level of knowledge and level of practice, level of knowledge, level of practice and referral rate in maternal cases, pediatrics, adolescents, adults, and elderly can be seen in Table 4. 
Table 4. The relationship between level of knowledge, level of practice and referral rate in maternal cases, pediatrics, adolescents, adults, and elderly.

\begin{tabular}{|c|c|c|c|}
\hline No & Variable & $\begin{array}{c}\text { Prevalance Ratio } \\
\text { 95\% Confidence Interval }\end{array}$ & $P$ value \\
\hline 1 & $\begin{array}{l}\text { Maternal cases: } \\
\text { Knowledge and practice } \\
\text { Knowledge and referral } \\
\text { Practice status and referral }\end{array}$ & $\begin{array}{c}7.778, \\
1.200-50.424 \\
1.375 \\
0.158-11.937 \\
5.143 \\
0.445-59.456\end{array}$ & $\begin{array}{l}0.024 * \\
0.772 \\
0.162\end{array}$ \\
\hline 2 & $\begin{array}{l}\text { Pediatric cases: Knowledge and practice } \\
\text { Knowledge and referral } \\
\text { Practice status and referral }\end{array}$ & $\begin{array}{c}3.500, \\
0.628-19.496 \\
3.733 \\
0.646-21.577 \\
3.733 \\
0.646-21.577 \\
\end{array}$ & $\begin{array}{l}0.146 \\
0,133 \\
0,133 \\
\end{array}$ \\
\hline 3 & $\begin{array}{l}\text { Adolescent cases: } \\
\text { Knowledge and practice } \\
\text { Knowledge and referral } \\
\text { Practice status with referral rates }\end{array}$ & $\begin{array}{c}110.000 \\
6,046-2001,3244.125 \\
0,360-47,304 \\
4,125 \\
0,360-47.304\end{array}$ & $\begin{array}{l}0.000^{*} \\
0.231 \\
0,231\end{array}$ \\
\hline 4 & $\begin{array}{l}\text { Adult cases: Knowledge and practice } \\
\text { Knowledge and referral } \\
\text { Practice status and referral }\end{array}$ & $\begin{array}{c}30.000 \\
2.626-342.734 \\
5.625 \\
0.537-58.9099 .167 \\
0.860-97.694\end{array}$ & $\begin{array}{c}0,001 * \\
0.123 \\
0.043^{*}\end{array}$ \\
\hline 5 & $\begin{array}{l}\text { Geriatric cases: Knowledge with practice } \\
\text { Knowledge with referral } \\
\text { Practice status with referral }\end{array}$ & $\begin{array}{c}19.500 \\
2.192-173.486 \\
6.125 \\
0.597-62.821 \\
6.125 \\
0.597-62.821\end{array}$ & $\begin{array}{l}0,003 * \\
0.101 \\
0.101\end{array}$ \\
\hline
\end{tabular}

Chi square, significant $\mathrm{p}<0.05$

\section{DISCUSSION}

Subjects' gender was found related with the level of knowledge and practice levels of maternal cases requiring rehabilitation services. In this study, subjects were predominantly female $(65.20 \%)$. Female gender is considered as a protective factor against lacking level of knowledge in maternal cases. Female doctors will be more concerned to study and practice maternal cases compared to male doctors because of their status as women, with some of the subjects possessing maternal experience. The knowledge and behavior (practice) was influenced by predisposing factors namely gender. ${ }^{2}$

Employment status relates to the referral rates of geriatric cases that require rehabilitation services. The employment status of study subjects consisted of $56.0 \%$ civil servants, $34.80 \%$ BLUD employees, and $8.70 \%$ private workers. Most cases that require rehabilitation services in primary health care were elderly cases and these elderly cases require referral. Primary health care (Puskesmas) doctors with $P N S$ status are considerably more favourable in 
case referral as a result of $P N S$ doctors having a longer service period, and older by age compared to non- $P N S$ employees. The knowledge and behavior (practice, referral) was influenced by predisposing factors namely employment status. ${ }^{2}$

The results showed that $56.50 \%, 56.50 \%$, and $82.60 \%$ subjects had lack level of knowledge, practice, and referral in maternal case, respectively. Research subjects $56.50 \%$ had lack pediatrics referral rate. Subjects $52.20 \%$ had lack level of knowledge and practices and $82.60 \%$ lack referral adolescent cases. Subjects $52.20 \%$ and $73.90 \%$ had lack practices and referral rates of adult cases, respectively. Subjects $65.20 \%$ had lack referral rate geriatric cases. Lack of knowledge of Puskesmas doctors about maternal and adolescent cases, lack of practice in maternal, adolescent and adult cases that require rehabilitation services can be addressed by conducting training by associations of specialist doctors of physical medicine and rehabilitation. Most research subjects were lack in referring maternal, child, adolescent, adult and elderly cases that require rehabilitation services. The training contains knowledge and practices on continuum of care cases that require rehabilitation services that can be carried out in primary health care and cases that must be referred to secondary and tertiary health services. ${ }^{3-10}$

There was relationship between the level of knowledge and the level of practice in maternal cases, adolescent cases, adult cases and elderly cases and the level of practice of elderly cases. Practice is influenced by knowledge. ${ }^{2}$ The ability to carry out rehabilitation practices in maternal, adolescent, adult and elderly cases by doctors in primary health care was influenced by the level of knowledge about rehabilitation in maternal, adolescent, adult, and elderly cases. Knowledge about rehabilitation of maternal, adolescent, adult and elderly cases can be obtained from medical education, attending seminars and courses on rehabilitation, reading articles about rehabilitation in journals or the internet. Doctors who work in Primary Health Services have never received sufficient education about rehabilitation while undergoing medical education. Doctors who work in Primary Health Services never get enough education about rehabilitation while undergoing medical education, have never attended a seminar or course on rehabilitation and have never or rarely read articles about rehabilitation from a journal or the internet.

There was relationship between the level of practice and the referral rate in adult cases. The ability to make a referral to secondary or tertiary health services were influenced by the knowledge of the competence of doctors in primary health services and the competence of specialist doctors including physicians in physical and rehabilitation medicine and practices carried out on maternal, adolescent, adult and elderly cases that require rehabilitation services. ${ }^{2}$ The knowledge and behavior (practice) was influenced by predisposing factors namely gender, age, level of education, economic status, experience; enforcing factors such as peer exposure; enabling actors namely legal aspects and access. ${ }^{2}$

In all research subjects, management of continuum of care cases were funded from the government's national health insurance (BPJS), therefore no subjects were able to make a direct referral to a physical and rehabilitation medicine clinicial. All primary health center (Puskesmas) doctors were familiar with the presence of doctors in Physical Medicine and Rehabilitation. All cases 
of continuum of care that require rehabilitation services were referred to specialists in Obstetrics and Gynecology, Pediatricians, Internal Medicine, Neurologists, Surgeon, and Orthopedic Surgeons. Most of the study subjects have communicated with their patient to inform the specialist that they require rehabilitation service.

\section{CONCLUSION}

Gender was related to the level of knowledge and practice in maternal cases, Employment status was related to the referral rates of geriatric cases, the level of knowledge was related with the level of practice in maternal cases, adolescent cases, adult cases and elderly cases, the level of practice was related with the referral rate in adult cases that need continuum rehabilitation services.

\section{REFERENCES}

1. Kementerian Perencanaan Pembangunan Nasional/Badan Perencanaan Pembangunan Nasional. National Development Agenda. Jakarta : Kementerian Perencanaan Pembangunan Nasional, 2014

2. Sharma M, Romas JA. Theoretical Foundations of Health Education and Health Promotion, 2nd ed. Sudbury, MA: Jones and Bartlett; 2012.

3. Christensen KS, Hansen DG. The role of the general practitioner in rehabilitation. Ugeskr Laeger. 2014 May 12;176 (10). pii: V01140066.

4. Thorsen O, Hartveit M, Baerheim A. General practitioners' reflections on referring: An asymmetric or non-dialogical process? Scandinavian Journal of Primary Health Care. 2012; 30: 241-246.

5. $\mathrm{Yu} \mathrm{W}$, et al. Practices and Attitudes of Doctors and patients to downward referral in Shanghai, Cina. BMJ Open. 2017;7:e012565. Doi: 10.1136/bmjopen-2016-012565

6. S Maidment. Tips for GP trainees working in rehabilitation medicine. British Journal of General Practice. 2014; 64: 206-207

7. Jan Stratil, Monika A. Rieger, Susanne Voelter-Mahlknecht. Optimizing cooperation between general practitioners, occupational health and rehabilitation physicians in Germany: a qualitative study. Int Arch Occup Environ Health.2017; 90:809-821. DOI 10.1007/s00420-017$1239-6$

8. McColl MA, Shortt S, Godwin M, Smith K, Rowe K, O’Brien P, Donnelly C. Models for integrating rehabilitation and primary care: a scoping study. Arch Phys Med Rehabil. 2009;90:1523-31.

9. Egerton et al. General practitioners' views on managing knee osteoarthritis: a thematic analysis of factors influencing clinical practice guideline implementation in primary care. BMC Rheumatology.2018; 2:30 https://doi.org/10.1186/s41927-0180037-4.

10. Jennings AA, Foley T, Walsh KA, Coffey A, Browne JP, Bradley CP. General practitioners' knowledge, attitudes, and experiences of managing behavioural and psychological symptoms of dementia: A mixed-methods systematic review. Int $\mathrm{J}$ Geriatr Psychiatry. 2018;33:1163-1176. 